\title{
The impact of COVID-19 on church gatherings in the Philippines: a policy analysis
}

\section{Grace Zurielle Malolos ${ }^{a}$, Joseph Christian Obnial ${ }^{b}$, Rena Mallillinc, Pamela Bianca Pasco $^{a}$, Erika Ong ${ }^{a}$, Arianne Andes ${ }^{d}$, Faith Ann Apat ${ }^{\mathrm{e}}$, Emma Teresa Carmela Aportadera $^{b}$, Rafael Valencia ${ }^{f}$ and Don Eliseo III Lucero-Prisno ${ }^{\mathrm{g}}$}

${ }^{\text {a }}$ College of Medicine, University of the Philippines Manila, Manila, Philippines

${ }^{b}$ Faculty of Medicine and Surgery, University of Santo Tomas, Manila, Philippines

${ }^{c}$ Ateneo de Manila University School of Medicine and Public Health, Pasig City, Philippines

d JONELTA Foundation School of Medicine, University of Perpetual Help Rizal, Las Piñas City, Philippines

e Matias H. Aznar Memorial, College of Medicine, Cebu City, Philippines

${ }^{f}$ University of the Philippines Diliman

g Department of Global Health and Development, London School of Hygiene and Tropical Medicine, London, United Kingdom

\begin{abstract}
The Philippines is the largest Christian-majority country in Asia. With church gatherings playing a vital role in the nature of Christianity in the Filipino culture, the advent of the coronavirus disease (COVID-19) pandemic in the Philippines posed challenges to public religious practices amid efforts to mitigate COVID-19 community transmission. Various policy pronouncements from both the government-led InterAgency Task Force (IATF) on Emerging Diseases and the church-led Catholic Bishops' Conference of the Philippines (CBCP) were issued. These guidelines were implemented in order to address the two-pronged problem on healthcare and religious obligations. While these guidelines were initially contributory to the mitigation of disease transmission, varied compliance by Filipinos was observed through the progression of the pandemic. Considering the value that church gatherings and religion play in the lives of the Filipino people, further studies on COVID-19 transmission in the church should be conducted in order to develop more efficient policies and guidelines on the practice of religion, particularly for religious gatherings. Furthermore, a more synergistic state and church cooperation must be encouraged in order to arrive at solutions that will mutually address the concomitant problems of the COVID-19 pandemic.
\end{abstract}

Key words: COVID-19, Philippines, policy analysis, state and church cooperation 


\section{Introduction}

The first confirmed cases of the coronavirus disease (COVID-19) in the Philippines were in January $2020 .{ }^{1}$ In the following months, the numbers escalated, rising second only to Indonesia in the Southeast Asian region, with 1,006,428 confirmed cases by April 26, 2021. ${ }^{2}$ The continuous rise in the number of cases and the swift escalation of the pandemic prompted the Philippine government to enact sweeping measures to curtail the spread of COVID-19. By March 2020, community transmission was already evident, and the government announced community quarantine, or the lockdown of the National Capital Region (NCR) and its surrounding provinces.

The community quarantine restrictions resulted in the prohibition of many social activities, including religious gatherings. With the Philippines being a largely Catholic country comprising 79.5 percent of its religious and Christian affiliation, restrictions on religious gatherings dealt a heavy blow to a large aspect of Filipino life. $^{3}$ In a survey conducted in December 2019, 83 percent of adult Filipino Catholics surveyed regarded religion as very important to their lives, with 45 percent of the total respondents reporting to have attended religious services weekly. ${ }^{4}$ Even with an ongoing pandemic, 62 percent of respondents in a survey in May 2020 still want church gatherings to resume in areas under community quarantine. ${ }^{5}$ Therefore, it is imperative to review the policies instituted by both the government and church authorities during the pandemic and examine the response of the Filipino devout regarding their practice of religion amidst this global health crisis.

\section{The Practice of Faith in the Philippines}

Religion is central to the lives of Filipinos, as the Philippines ranks fifth among the most religious countries globally. ${ }^{6}$ With over 79.5 percent of its population baptized as Catholics, it is the largest Catholic nation in Asia. A comparison of cross- national trends in religious service attendance among various countries indicated that the Philippines has a high and stable religious service attendance, with attendance rates of Catholic church members reaching 84 percent and 80 percent during the late 1990 s and early 2000 s, respectively. ${ }^{7}$

Faith plays a pivotal role in the life of most Filipinos, existing not only as an abstract belief system but also as a host of ceremonies, rituals, and experiences. Religion provides continuity in life, cohesion in the community, and moral purpose for existence. ${ }^{8}$ It renders spiritual solace and guidance in times of crisis, more so in the midst of a global pandemic. ${ }^{9}$ Even among the Filipino diaspora, the church remains vital in shaping migrant populations. For them, it functions as a means of social control, a center of collective identity, and a source of empowerment. ${ }^{10}$

\section{Government Guidelines and Policies on}

\section{Religious Gatherings}

The Philippine government responded by calling together the Inter-agency Task Force on Emerging Diseases (IATF), headed by the Secretary of the Philippine Department of Health. Upon its recommendation, NCR was placed under "stringent social distancing measures" on March 12, 2020. ${ }^{11}$ On March 16, 2020, a state of calamity was declared throughout the Philippines, and Enhanced Community Quarantine (ECQ) was imposed in Luzon with only essential services allowed to operate (e.g., groceries, utilities, etc.). As far as religious activities were concerned, religious ministers were only allowed to conduct funeral rites. ${ }^{11}$

Quarantine guidelines were modified and further consolidated with subsequent meetings of the IATF, summarized in Table 1. On April 29, 2020, the first version of the Omnibus Guidelines on the Implementation of Community Quarantine in the Philippines was released to "harmonize and codify the existing policies." 12 Mass gatherings, with 
explicit mention of religious gatherings, were prohibited for areas under ECQ and the less stringent General Community Quarantine (GCQ). ${ }^{12}$ On May 15,2020 , the conduct of GCQ was modified further, and additional guidelines were issued for two more quarantine classifications-the Modified Enhanced Community Quarantine (MECQ) and Modified
General Community Quarantine (MGCQ). ${ }^{13}$ For MECQ, religious gatherings would be allowed but were limited to not more than five persons, and only 50 percent of the seating capacity of the church was permitted for MGCQ. ${ }^{13}$ Meanwhile, GCQ restrictions were loosened to not more than 10 persons allowed at religious gatherings.

Table 1. The four levels of quarantine in the Philippines, from most stringent to the least.

\begin{tabular}{|c|c|c|}
\hline Category & & Restrictions on Religious Gatherings \\
\hline ECQ & & $\begin{array}{l}\text { Religious gatherings are prohibited } \\
\text { Only funeral rites allowed }\end{array}$ \\
\hline \multirow[t]{2}{*}{ MECQ } & May 15,2020 & Not more than five persons allowed per religious gathering \\
\hline & Apr 12, 2021 & $\begin{array}{l}\text { Until } 10 \% \text { seating capacity, with Local Government Units (LGUs) having the power to } \\
\text { prohibit or increase it until } 30 \%\end{array}$ \\
\hline \multirow[t]{6}{*}{ GCQ } & May 1,2020 & Same restrictions as ECQ on religious gatherings \\
\hline & May 15,2020 & Not more than 10 persons per gathering \\
\hline & July 2,2020 & Until $10 \%$ seating capacity or 10 persons \\
\hline & October 22,2020 & Until $30 \%$ seating capacity \\
\hline & February 15,2021 & Until $50 \%$ of the venue capacity \\
\hline & March 22, 2021 & $\begin{array}{l}\text { Religious gatherings are prohibited } \\
\text { Weddings, baptisms, funerals are limited to } 10 \text { persons }\end{array}$ \\
\hline MGCQ & & $50 \%$ of church seating capacity permitted \\
\hline
\end{tabular}

Note: ${ }^{*}$ The specific guidelines under each classification may change as the government sometimes revises policy.

On July 2, 2020, restrictions on religious gatherings under GCQ were relaxed to allow up to 10 percent of the seating capacity (or 10 people, whichever is higher). Churches were also officially allowed to reopen in July 2020 under the assumption that churches will only be used for the sole purpose of religious services. Concomitantly, churches were required to observe minimum public health standards, such as social distancing protocols and the use of face masks, in conducting gatherings within their premises. ${ }^{14}$

On October 22, 2020, restrictions were further relaxed to allow up to 30 percent of the seating capacity. ${ }^{15}$ Additional provisions were added to the IATF guidelines by December 2020, requiring the use of face shields when leaving residences, including going to church. ${ }^{16}$ Starting February 15, 2021, the government permitted churches under GCQ to operate at up to 50 percent seating capacity, just two days before Ash Wednesday, which signals the beginning of the Lenten season. ${ }^{17}$ However, on March 22, 2021, a few days before the beginning of Holy Week, the government completely prohibited religious gatherings due to a surge in active COVID19 cases. ${ }^{18-20}$ 
With mixed reactions by Catholic and Protestant religious leaders, ${ }^{21,22}$ the government conceded to permit religious gatherings once a day at 10 percent seating capacity by March 26, 2021.23 However, this decision was retracted the following day when Metro Manila, along with some of its surrounding provinces, was placed under ECQ for the entirety of the Holy Week $2021 .^{24}$

Beyond the imposition of guidelines, the national government and the local government units (LGUs) have also consistently worked with church officials to ensure proper maintenance of health protocols upon the resumption of regular church activity. LGUs created technical working groups to coordinate plans for large religious festivities. Members of the police were routinely dispatched during religious gatherings with traditionally high public turnout, such as masses during Christmas season. ${ }^{25,26}$ The Department of Health periodically releases statements and directives to guide LGUs in the conduct of religious celebrations, such as orders for attendees to fill up contact tracing forms and the performance of regular temperature checks. ${ }^{27}$

\section{Guidelines of the Religious Leadership on Religious Gatherings}

The Catholic Church largely responded by following the guidelines of the IATF, such as shifting worship to online platforms and limiting church capacity. Individual dioceses were the first to take initiatives in suspending masses at the start of the pandemic before guidelines were instituted by the Catholic Bishops' Conference of the Philippines (CBCP) ${ }^{28}$ The CBCP subsequently released their own guidelines in response to government and health regulations. ${ }^{29}$ The primary modification of live activities was through televising and online streaming of most church services. ${ }^{28,29}$ The CBCP further elaborated on guidelines upon the easing of community quarantine, such as the use of thermal scanners, foot baths, and hand sanitizers. It gave instructions on proper entrance and exit areas and

July 2021. Christian Journal for Global Health 8(1) social distancing with markers on pews and standing areas. Attendees were required to use face masks during church services. ${ }^{30}$ Mass practices were also modified, such as the omission of the offertory procession and the strict implementation of receiving the host by the hand and not directly to the mouth. Some parishes offered drive-in masses to avoid public crowding in their church and developed mobile phone applications for use by its parishioners. ${ }^{31,32}$

Certain Catholic traditions and practices in the Philippines were also modified. At the start of community quarantine in March 2020, the CBCP published instructions for Holy Week celebrations to be held in the same month. ${ }^{33}$ The blessing of palms on Palm Sunday was suspended and replaced by verbal blessings around the streets of the parish. Similarly, Simbang Gabi or Night Mass, a nine-day series of masses culminating in Christmas Eve, usually held between 3 a.m. to 5 a.m., were permitted to be held as early as 6:00 p.m. in response to curfew hours mandated by LGUs. ${ }^{34}$ In addition, church officials encouraged holding masses more frequently in order to properly distribute the number of attendees. ${ }^{34}$

Along with traditional practices in the Philippines, various Catholic religious festivals are held in different parts of the country. Numerous modifications were also instituted to conduct these festivities. For one, the Philippines is celebrating 500 years of Christianity in 2021, initially planned to be a large affair. However, with the pandemic stretching into 2021, the quincentennial anniversary will now be a year-long celebration, beginning April 2021, and with grand culminating activities postponed for April 2022. ${ }^{35}$ Some festival events were initially allowed, but because of local spikes in active COVID-19 cases, all of the festival's physical activities, with the exception of masses, were cancelled. ${ }^{36-38}$

Perhaps one of the most significant changes to religious festivities is the modification of the Feast of the Black Nazarene held every January. 
Traslacion, the yearly 6-kilometer procession of the image of the Black Nazarene around Manila, was cancelled. Instead, consecutive masses were held within Quiapo Church, limiting each mass to only 400 participants, or 30 percent of the church's capacity, in line with the guidelines..$^{39,40}$ In addition, simultaneous novena masses were held in numerous parishes within Metro Manila to accommodate more distant devotees. The tradition of kissing the Black Nazarene image by devotees, or pahalik, was also prohibited. $^{40}$ In lieu of this practice, the Black Nazarene was placed in front of the church for viewing by the public. Sanitation efforts were also performed by church volunteers before every new batch of devotees could occupy the viewing areas. ${ }^{40}$

\section{Impacts of COVID-19 on Other}

\section{Christian Denominations in the}

\section{Philippines}

Other prominent Christian denominations in the Philippines include the evangelicals, represented by the Philippine Council of Evangelical Churches (PCEC) and the Iglesia ni Cristo (INC), comprising 2.4 and 2.6 percent of the population, respectively. Although the INC initially planned to allow their gatherings despite government guidelines, ${ }^{41}$ they now utilize online streaming in areas with sufficient internet access and conduct household worship services in areas with relatively limited connectivity. ${ }^{42}$

The evangelicals responded to the government guidelines in a similar way by conducting online streaming of their religious services and requiring the observation of minimum public health standards. ${ }^{43}$ Pre-registrations were also employed for the purpose of initial health screening and ensuring seating capacity compliance. ${ }^{44,45}$ Biannual prayer and fasting traditions by some evangelical churches were also moved online, with the provision of prayer and fasting guides and virtual prayer rooms to enable fellowship among their religious members. ${ }^{45,46}$

July 2021. Christian Journal for Global Health 8(1)

\section{Compliance and Reception of Filipinos}

\section{to Church Gathering Policies}

A survey released in September 2020 by Pulse Asia's Ulat ng Bayan revealed that among 1200 respondents around the Philippines, 51.8 percent have become more religious during the COVID-19 pandemic. This provides a glimpse of the value of Christian faith to the Filipino in times of crisis. ${ }^{47}$ While the pandemic has limited religious gatherings in the Philippines, it has transformed the Christian devotion of many Filipinos from being reliant on external practices to internal reflection. ${ }^{48}$

Contrary to other countries, where outbreaks have happened as a result of religious activities, ${ }^{49}$ initial COVID-19 outbreak reports in the Philippines noted clusters resulted from social events, such as wakes or birthday parties. ${ }^{50}$ In August 2020, reports on COVID-19 transmission in the Philippines were primarily healthcare facility-, prison-, or workplacebased. ${ }^{51}$ The strict lockdown instituted at the start of the pandemic contributed largely to the adherence of the Filipinos on policies regarding church gatherings. Due to the fact that the parishes themselves were prohibited from opening their church to live masses, the public was compelled to adapt to by attending live streamed masses at their own homes.

Filipinos also complied with modifications of other religious traditions, especially during the Lenten season, observed at the height of the community lockdown. Along with online masses, videos by devotees shared ways on how to observe the season at home, such as instructions on making homemade palm crosses from palm fronds and makeshift altars. ${ }^{52}$ Instead of gathering outside their homes for the blessing of the palm fronds on Palm Sunday, parishioners opted to set up the fronds on tables in the streets for the blessing of the priest going around the neighborhood. ${ }^{53}$

Public novenas during Lent, or pasyon, usually initiated by devotees in their backyards, were put on hold and were instead conducted privately within 
homes. Some even used PowerPoint presentations to conduct certain prayers, such as The Way of the Cross or Via Crucis. However, despite guidelines prohibiting any form of public or religious gathering, Holy Week rituals such as self-flagellation on Good Friday were still initiated by devotees and were done publicly outside closed churches. ${ }^{54}$

Relaxation of guidelines were eventually observed for the remainder of 2020, consequently resulting in church gatherings being permitted during the Christmas season. ${ }^{55}$ Multiple reports state that the public and their respective parishes were compliant with the guidelines instituted by the government and the CBCP. Observations by authorities in Southern Metro Manila showed orderly and peaceful night masses, with proper social distancing. However, mass turnouts were still high despite the pandemic, ${ }^{17}$ resulting in some parishes becoming over-crowded. ${ }^{18}$

Similar to religious holiday traditions and practices, the celebration of religious festivals also posed an additional threat to the mitigation of COVID-19 in the Philippines. The most important of these is the Feast of the Black Nazarene held on January 9, 2021. Public turnout was still heavy, with an estimated 400,000 people attending, despite multiple warnings of the activity being a potential super-spreader event. ${ }^{56-58}$ Nonetheless, this was significantly lower than annual numbers, as this procession draws in millions of devotees each year, which may signify that a large majority of Filipino Catholics adhere to the restrictions and are wary of the dangers of the pandemic. Even among attendees, strict social distancing measures were implemented, and photos of the crowds show that devotees were largely compliant, standing at least 1-meter apart from each other. ${ }^{57,58}$

\section{State and Church Cooperation in the}

\section{time of the COVID-19 Pandemic}

With the advent of the COVID-19 pandemic in the Philippines, both the state and the church

July 2021. Christian Journal for Global Health 8(1) responded through the near-simultaneous implementation of IATF and $\mathrm{CBCP}$ guidelines on religious gatherings. In addition, both sectors appeared to be cooperative with each other, evidenced by their coordinated mitigation efforts during high-volume events. At face value, guidelines on religious gatherings were adequately complied with by Filipinos. However, the Philippine government's general COVID-19 response was met with the disapproval of 53.7 percent of Filipino respondents of The State of Southeast Asia: 2021 survey, ${ }^{59}$ prompting questions on its effectiveness and in consistently mitigating the spread of COVID19.

Despite not being primarily attributed to religious gatherings, ${ }^{50}$ COVID-19 transmission in the Philippines saw notable fluctuations during the Christmas season and the start of the year, ${ }^{60,61}$ during which church gatherings were of heightened importance. This was observed with an increase in the reproductive number or $\mathrm{R}_{0}$, from 1.06 to 1.15 in Metro Manila two weeks before Christmas. ${ }^{60,61}$ Even at the start of the new year in 2021, upward trends were reported with increases in $\mathrm{R}_{0}$ to $1.17 .{ }^{61}$ These numbers did not significantly go down as the $\mathrm{R}_{0}$ in NCR peaked at 2.21 by March 23, 2021, just a few days before the celebration of Holy Week. ${ }^{62}$

Given this, it can be surmised that while these guidelines appear to be contributory to COVID-19 mitigation in the Philippines, its impact with regards to major religious celebrations remains debatable. Likewise, the effect of major religious celebrations in spreading the virus is still unknown. The lack of available data on religious gatherings during the COVID-19 pandemic limits the understanding of these on conjectures and unverified correlations. Hence, further studies on COVID-19 transmissions in the setting of religious gatherings, as well as on the effectiveness of present guidelines must be done in order to develop evidence-based and specific guidelines on religious gatherings.

What remains certain is that with the importance and the fundamental role of religion to 
Filipinos, a more proactive approach must be taken in order to more adequately address the impact of COVID-19 on religious gatherings. Through open communication and meaningful collaboration among the church, the state, and the general public, all factors can be adequately addressed. Effective monitoring and evaluation can identify points of improvement and ensure a more effective response.

With its aforementioned value to Filipinos, and its societal, cultural, and traditional roots, future guidelines and policies must also take church gatherings and religion into major consideration. The pandemic has shown that mutual cooperation between the government and religious institutions has been beneficial to everyone in this time of emergency; since, ultimately, their constituents are one and the same, the general public. ${ }^{63}$ This is evident in other countries that were able to demonstrate it is possible for religion and the government to cooperate, such as in Germany and in neighboring Vietnam. ${ }^{63,64}$ While the Philippine Constitution states that the separation of the state and church must be inviolable, it is evident that the two must work together in mitigating the COVID-19 community transmission and its concomitant problems, highlighting the importance of a multisectoral approach to healthcare.

\section{Conclusion}

The high percentage of people expected to observe church services and religious practices despite the pandemic has demonstrated the deepseated nature of religion in Filipino culture. With the importance given to consistent church attendance by Filipinos, it is recommended that further studies on COVID-19 transmission in the church be done to further develop more specific guidelines in line with religious practices. Ultimately, a multisectoral and collaborative approach must be taken in addressing the concomitant problems of the COVID-19 pandemic.

July 2021. Christian Journal for Global Health 8(1)

\section{References}

1. Edrada EM, Lopez EB, Villarama JB, Salva Villarama EP, Dagoc BF, Smith C, et al. First COVID-19 infections in the Philippines: a case report. Trop Med Health. 2020;48(1):21. http://doi.org/10.1186/s41182-020-00203-0

2. Department of Health. Beat COVID-19 today: a COVID-19 Philippine situationer. Report No.: Issue 265. [Internet]. Philippines: Department of Health. 2021 [updated 2021 Apr 27] [cited 2021 Apr 28]. Available from: https://doh.gov.ph/2019-nCoV

3. 2019 Philippine statistical yearbook [Internet]. 2019 Oct [cited 2020 Dec 29]. Available from: https://psa.gov.ph/sites/default/files/2019PSY 1003.pdf

4. Social weather stations | Fourth quarter 2019 Social Weather Survey: record-high $83 \%$ of adult Filipinos say religion is "very important." [cited 2021 Feb 2] Available from:

http://www.sws.org.ph/swsmain/artcldisppage/?artcsy $\underline{\text { scode }=\text { ART }-20200412155426}$

5. Patinio F. More Pinoys want masses resumed amid quarantine: church survey [Internet]. Philippine News Agency. 2020 May 19 [cited 2020 Dec 29]. Available from: https://www.pna.gov.ph/articles/1103300

6. Merez A. PH among world's most religious countries: study [Internet]. ABS-CBN News. 2018 May 9 [cited 2020 Dec 29]. Available from: https://news.abscbn.com/news/05/09/18/ph-among-worlds-mostreligious-countries-study

7. Brenner P. Cross-national trends in religious service attendance. Publ Opin Q. 2016;80(2):563-83. https://doi.org/10.1093/poq/nfw016

8. Dolan R. Philippines: a country study [Internet]. Country studies. 1991 [cited 2020 Dec 29]. Available from: http://countrystudies.us/philippines/

9. Yee V. In a pandemic, religion can be a balm and a risk. New York Times. 2020 Mar 22 [cited 2021 Apr 23]. Available from: https://www.nytimes.com/2020/03/22/world/middleea st/coronavirus-religion.html

10. Fresnoza-Flot A. The Catholic church in the lives of irregular migrant Filipinas in France: identity formation, empowerment and social control. Asia Pac J Anthropol. 2010;11(3-4):345-61. http://doi.org/10.1080/14442213.2010.511628 
11. Resolutions relative to the management of the coronavirus diseases 2019 (COVID19) situation [Internet]. [Resolution no. 11; Series of 2020]. 2020 March 12 [cited 2020 Dec 29]. Available from: https://doh.gov.ph/sites/default/files/healthupdate/IATF-RESO-11.pdf

12. Omnibus guidelines on the implementation of community quarantine in the Philippines [Internet]. Presidential Communications Operations Office. 2020 Apr 29 [cited 2020 Dec 29]. Available from: https://pcoo.gov.ph/wpcontent/uploads/2020/05/Omnibus-Guidelines-on-theImplementation-of-Community-Quarantine-in-thePhilippines.pdf

13. Omnibus guidelines on the implementation of community quarantine in the Philippines [Internet]. 2020 May 15 [cited 2020 Dec 29]. Available from: https://pcoo.gov.ph/wpcontent/uploads/2020/05/Omnibus_guidelines.pdf

14. Inter-Agency Task Force for the Management of Emerging Infectious Disease Resolution [Internet]. 2020 July 2 [cited 2020 Dec 19];51. Available from: https://pcoo.gov.ph/wpcontent/uploads/2020/07/IATF_Res.No_.51.pdf

15. Inter-Agency Task Force for the Management of Emerging Infectious Disease Resolution [Internet]. 2020 Oct 22 [cited 2020 Dec 29];80. Available from: https://pcoo.gov.ph/wpcontent/uploads/2020/10/IATF-Resolution-No.-80.pdf

16. Inter-Agency Task Force for the Management of Emerging Infectious Disease Resolution [Internet]. 2020 Dec 14 [cited 2020 Dec 29];88. Available from: https://www.officialgazette.gov.ph/downloads/2020/1 2dec/20201214-IATF-Resolution-88-RRD.pdf

17. Religious gatherings under GCQ relaxed, allowed up to $50 \%$ seating capacity starting February 15 Presidential Communications Operations Office [Internet]. [cited 2021 May 15]. Available from: https://pcoo.gov.ph/news releases/religiousgatherings-under-gcq-relaxed-allowed-up-to-50seating-capacity-starting-february-15/

18. Inter-Agency Task Force for the Management of Emerging Infectious Disease Resolution [Internet]. 2021 Oct 20 [cited 2021 May 10];104. Available from: http://www.exteriores.gob.es/Consulados/MANILA/e
s/Consulado/Documents/IATF\%20Resolution\%20104 $\% 20 \mathrm{March} \% 2020 \% 202021 . \mathrm{pdf}$

19. Talabong R. PH restricts cross-border travel, mass gatherings in NCR, 4 provinces. Rappler [Internet]. 2021 Mar 21 [cited 2021 Apr 27]. Available from: https://www.rappler.com/nation/duterte-gcq-metromanila-bulacan-cavite-laguna-rizal-march-2021

20. Ranada P, Tomacruz S. Stricter GCQ, 'NCR Plus' bubble explained. Rappler [Internet]. 2021 Mar 22 [cited2021 Apr 27]. Available from: https:/www.rappler.com/nation/manila-archdiocesedefy-government-ban-holy-week-gatherings-2021

21. Esmaquel ER. Archdiocese of Manila to defy government ban on Holy Week gatherings. Rappler [Internet]. Published March 23, 2021. Accessed April 27, 2021. Available from: https://www.rappler.com/nation/manila-archdiocesedefy-government-ban-holy-week-gatherings-2021

22. Dagle RM. 'Unjust, inconsistent': Protestant churches hit 'NCR Plus' religious gathering ban. Rappler [Internet]. 2021 Mar 25 [cited Apr 27]. Available from: https://www.rappler.com/nation/protestantchurches-hit-ncr-plus-religious-gathering-ban

23. Ranada P. Gov't allows 'once a day' religious gatherings from April 1 to 4. Rappler [Internet]. 2021 Mar 26 [Cited 2021 Apr 27]. Available from: https:/www.rappler.com/nation/govt-allows-once-aday-religious-gatherings-from-april-1-to-4

24. CNN Philippines Staff. Metro Manila, four provinces shift to stricter ECQ for one week. CNN Philippines [Internet]. $2021 \mathrm{Mar} 27$ [cited 2021 Apr 27]. Available from: https://cnnphilippines.com/news/2021/3/27/ECQ2021-NCR-Plus-bubble.html

25. Filipinos flock to churches for 'Simbang Gabi' to pray for COVID-19 deliverance. INQUIRER.net. 2020 Dec 16 [cited 2021 Jan 29]. Available from: https://newsinfo.inquirer.net/1372409/filipinos-flockto-churches-for-simbang-gabi-to-pray-for-covid-19deliverance

26. Rita J. Simbang Gabi attendees fail to keep distancing rule in some Cebu parishes. GMA News Online. 2020 Dec 16 [cited 2021 Jan 29]. Available from: https://www.gmanetwork.com/news/news/regions/768 185/simbang-gabi-attendees-fail-to-keep-distancingrule-in-some-cebu-churches/story/ 
27. Joint statement on preventing a post-holiday surge [Internet]. Department of Health. 2020 Dec 17 [cited $2021 \mathrm{Feb} 2]$. Available from:

https://doh.gov.ph/press-release/joint-statement-onpreventing-a-post-holiday-surge

28. Lagarde R. Several dioceses suspend masses due to coronavirus [Internet]. CBCP Monitor. 2020 [cited $2021 \mathrm{Feb} 1] .24(6)$. Available from: https://cbcpnews.net/cbcpnews/wpcontent/uploads/2020/03/vol24-no06.pdf

29. Valles R. Recommendations and guidelines for the liturgical celebration in 'new normal' condition [Internet]. CBCPNews. 2020 May 16 [cited 2020 Dec29]. Available from: https://cbcpnews.net/cbcpnews/liturgical-guidelinesin-new-normal-condition/

30. del Castillo FA, Biana HT, Joaquin JJB. ChurchInAction: the role of religious interventions in times of COVID-19. J Public Health. 2020;42(3):6334. http://doi.org/10.1093/pubmed/fdaa086

31. Sorote RC. Leyte church offers 'drive-in' mass amid pandemic [Internet]. CBCPNews. 2020 Sept 15 [cited $2021 \mathrm{Feb} 1]$. Available from:

https://cbcpnews.net/cbcpnews/leyte-church-offersdrive-in-mass-amid-pandemic/

32. Quiapo Church goes mobile to reach out devotees [Internet]. CBCPNews. 2020 Oct 20 [cited $2021 \mathrm{Feb}$ 2]. Available from: https://cbcpnews.net/cbcpnews/quiapo-church-gomobile-to-reach-out-devotees/

33. Valles R. Circular No. 20-15, re: Recommendations for the celebrations of the Holy Week during the quarantine period [Internet]. 2020 Mar 20 [cited 2020 Dec 29]. Available from: https://cbcpnews.net/cbcpnews/recommendations-forthe-celebrations-of-the-holy-week-during-thequarantine-period-2020/

34. Valles R. Instructions on the celebration of Aguinaldo Masses, Misa de Gallo or Simbang Gabi [Internet]. CBCPNews. 2020 Nov 27. Available from: https://cbcpnews.net/cbcpnews/instructions-on-thecelebration-of-aguinaldo-masses-misa-de-gallo-orsimbang-gabi/

35. Leslie A. COVID-19 forces bishops to postpone quincentennial celebration of Christianity in $\mathrm{PH}$. Manila Bulletin. 2020 Sept 24 [cited 2021 Feb 1]. Available from: https://mb.com.ph/2020/09/24/covid- 19-forces-bishops-to-postpone-quincentennialcelebration-of-christianity-in-ph/

36. Major Sinulog activities in Cebu cancelled over coronavirus [Internet]. CBCPNews. 2020 Nov 10 [cited $2021 \mathrm{Feb} 2$ ]. Available from: https://cbcpnews.net/cbcpnews/major-sinulogactivities-in-cebu-cancelled-over-coronavirus/

37. Macasero R. After cancellation of physical events, virtual Sinulog postponed too [Internet]. Rappler. 2021 Jan 9 [cited 2021 Jan 29]. Available from: https://www.rappler.com/nation/visayas/virtualsinulog-2021-postponed

38. National Youth Day postponed to 2022 [Internet]. CBCPNews. 2020 Dec 18 [cited 2021 Feb 2]. Available from: https://cbcpnews.net/cbcpnews/national-youth-daypostponed-to-2022/

39. Only 400 persons per mass allowed in Quiapo Church on Nazarene feast. CBCPNews [Internet]. 2021 Jan 6 [cited $2021 \mathrm{Feb} 2$ ]. Available from:

https://cbcpnews.net/cbcpnews/only-400-persons-permass-allowed-in-quiapo-church-on-nazarene-feast/

40. Ongcal A. How Covid affected one of the largest Catholic processions in the world [Internet]. 2021 Jan 11 [cited $2021 \mathrm{Feb} 2$ ]. Available from: https://www.vice.com/en/article/88avwz/blacknazarene-traslacion-2021-procession-religioncatholic-philippines-pandemic-covid-coronavirus

41. Manlupig K. Sara Duterte warns Iglesia ni Cristo: violate quarantine, face suit [Internet]. INQUIRER.net. 2020 Mar [cited 2021 Apr 22]. Available from: https://newsinfo.inquirer.net/1243063/sara-dutertewarns-inc-violate-quarantine-face-suit

42. Iglesia ni Cristo overcomes pandemic threat to distance people of faith from God [Internet]. Accesswire. 2021 Jan 5 [cited 2021 Apr 22]. Available from: https://www.accesswire.com/624487/Iglesia-NiCristo-Overcomes-Pandemic-Threat-to-DistancePeople-of-Faith-from-God

43. Gavilan J. LIST: Online masses, services by religious groups amid coronavirus [Internet]. Rappler. 2020 Apr 1 [cited 2021 Apr 22]. https://www.rappler.com/nation/list-online-massesservices-religious-groups-amid-coronavirus 
44. We are resuming our onsite worship services in Metro Manila! [Internet]. Victory - Honor God. Make Disciples. 2020 [cited 2021 May 15]. Available from: https://victory.org.ph/we-are-resuming-our-onsiteworship-services-in-metro-manila/

45. Intercede [Internet]. Christ's Commission Fellowship. [cited 2021 May 15]. Available from: https://www.ccf.org.ph/intercede/

46. Awesome God prayer \& fasting [Internet]. Victory Honor God. Make Disciples. [cited 2021 May 15]. Available from: https://victory.org.ph/fasting2021/

47. Cornelio J. [ANALYSIS] Are Filipinos more religious because of COVID-19 [Internet]? Rappler. 2020 Oct 23 [cited 2021 Apr 23]. Available from: www.rappler.com/voices/thought-leaders/analysisare-filipinos-more-religious-because-covid-19.

48. Calleja JP. Filipino faith perseveres despite pandemic restrictions [Internet]. UCAnews. 2020 Sept 30 [cited 2021 Apr 23]. Available from: www.ucanews.com/news/filipino-faith-perseveresdespite-pandemic-restrictions/89718\# .

49. Quadri S. COVID-19 and religious congregations: implications for spread of novel pathogens [Internet]. Int J Infec Dis. 2020 May 7 [cited 2021 Apr 23]. Available from: www.sciencedirect.com/science/article/pii/S12019712 20303131.

50. Haw NJL, Uy J, Sy KTL, Abrigo MRM. Epidemiological profile and transmission dynamics of COVID-19 in the Philippines. Epidemiol Infect. 2020;148. http://doi.org/10.1017/S0950268820002137

51. Tomacruz S. PH coronavirus cases surge past 106,000 , as DOH monitors 887 clusters [Internet]. Rappler. 2020 Aug 3 [cited 2020 Dec 29]. Available from: https://www.rappler.com/nation/coronaviruscases-philippines-august-3-2020

52. Esmaquel PI. Catholics in quarantine mark first online Holy Week [Internet]. Rappler. 2020 Apr 5 [cited 2021 Jan 29]. Available from: https://www.rappler.com/nation/catholics-quarantineonline-holy-week-2020

53. Kravchuk M. Covid-19 empties churches, but Holy Week rites continue online. OneNews.ph. [cited 2021 Feb 2]. https://www.onenews.ph/covid-19-emptieschurches-but-holy-week-rites-continue-online

July 2021. Christian Journal for Global Health 8(1)
54. Nepomuceno P. Unshaken faith: observing holy week amid COVID-19. 2020 Apr 8 [cited 2020 Jan 29]. Available from: https://www.pna.gov.ph/articles/1099225

55. Mongaya C. Christmas in the Philippines in the time of Duterte and COVID-19 [Internet]. Global Voices. 2020 Dec 31 [cited 2020 Jan 29]. Available from: https://globalvoices.org/2020/12/31/christmas-in-thephilippines-in-the-time-of-duterte-and-covid-19/

56. DOH reiterates reminder to devotees and calls on IGUS to monitor constituents who attend Traslacion [Internet]. Department of Health. 2021 Jan 9 [cited $2021 \mathrm{Feb} 1]$. Available from: https://doh.gov.ph/press-release/DOH-REITERATESREMINDER-TO-DEVOTEES-AND-CALLS-ONLGUs-TO-MONITOR-CONSTITUENTS-WHOATTEND-TRASLACION

57. Gregorio X. WHO says rise in COVID-19 cases "inevitable" after holidays [Internet]. Traslacion. Philstar.com. 2021 Jan 12 [cited 2021 Feb 2]. Available from:

https://www.philstar.com/headlines/2021/01/12/20699 21/who-says-rise-covid-19-cases-inevitable-afterholidays-traslacion

58. Portugal A, Lopez E. Philippines' Catholics show devotion to statue amid super-spreader worries [Internet]. Reuters. 2021 Jan 9 [cited 2021 Feb 2]. Available from: https://www.reuters.com/article/ushealth-coronavirus-religion-philippinidUSKBN29E03B

59. Seah S, Ha HT, Martinus M, Thao PT . The state of Southeast Asia: 2021 [Internet]. ISEAS-Yusof Ishak Institute, Singapore. $2021 \mathrm{Feb} 2$ [cited 2021 Apr 27]. Available from: https://iseas.edu.sg/wpcontent/uploads/2021/01/The-State-of-SEA-2021$\underline{\mathrm{v} 2 . \mathrm{pdf}}$

60. Metro Manila COVID-19 surge begins ahead of Christmas: OCTA Research [Internet]. ABS-CBN. 2020 Dec 22 [cited 2021 Feb 1]. Available from: https://news.abs-cbn.com/news/12/22/20/metromanila-covid-19-surge-begins-ahead-of-christmasocta-research

61. Galvez D. Research team marks 'clear upward trend' of Covid-19 cases in NCR [Internet]. INQUIRER.net. 2021 Jan 12 [cited 2021 Feb 2]. Available from: https://newsinfo.inquirer.net/1382791/research-teammarks-clear-upward-trend-of-covid-19-cases-in-ncr

CHRISTIAN JOURNAL GLOBAL HEALTH 
62. Hallare K. OCTA Research: COVID-19 cases 'unlikely' to go down in 2 weeks [Internet]. Inquirer. Net. 2021 Mar 23 [cited 2021 May 2]. Available from: https://cnnphilippines.com/news/2021/3/27/ECQ2021-NCR-Plus-bubble.html
63. Berkmann BJ. The Covid-19 crisis and religious freedom. J Law, Relig, State. 2020;8(2-3):179-200. http://doi.org/10.1163/22124810-2020013

64. Phuong, NT. Religion, law, state, and Covid-19 in Vietnam. J Law, Religion, State. 2020;8(2-3):284-97.

Peer Reviewed: Submitted 8 Feb 2021, accepted 19 May 2021, published 30 July 2021

Competing Interests: None declared.

Correspondence: Grace Zurielle Malolos, College of Medicine, University of the Philippines Manila, Manila, Philippines. gcmalolos@up.edu.ph

Cite this article as: Malolos GZ, Obnial JC, Mallillin R, Pasco PB, Ong E, Andes A, Apat FA, Aportadera ETC, Valencia R, Prisno DEL. The impact of COVID-19 on church gatherings in the Philippines: a policy analysis. Christian Journal for Global Health. July 2021; 8(1):53-63. https://doi.org/10.15566/cjgh.v8i1.505

(C) Authors. This is an open-access article distributed under the terms of the Creative Commons Attribution License, which permits unrestricted use, distribution, and reproduction in any medium, provided the original author and source are properly cited. To view a copy of the license, visit http://creativecommons.org/licenses/by/4.0/

\section{cjgh.org}

